\title{
Physical, chemical and sensory properties of gluten-free kibbeh formulated with millet flour (Pennisetum glaucum (L.) R. Br.)
}

\author{
Tcherena Amorim BRASIL ${ }^{1}$, Caroline Dário CAPITANI²*, \\ Katiuchia Pereira TAKEUCHI ${ }^{3}$, Tânia Aparecida Pinto de Castro FERREIRA ${ }^{4}$
}

\begin{abstract}
Pearl millet flour was utilized in kibbeh formulations instead of whole-wheat flour. Physicochemical properties, oxidation stability and sensorial characteristics of control kibbeh made with whole-wheat flour (CT) were compared with kibbehs prepared with millet flour (roasted or wet) and stored for 90 days $\left(-18^{\circ} \mathrm{C}\right)$. Kibbeh prepared with millet flour presented good oxidation stability (TBARS concentration). Baked kibbehs (with roasted millet flour) presented good acceptability and kibbeh samples did not differ significantly $(\mathrm{p}>0.05)$ from the whole-wheat flour sample, when global appearance, texture and flavor were evaluated. Millet flour could be a suitable ingredient for kibbeh formulations, maintaining their nutritional value and sensorial quality in addition to being a gluten-free product.
\end{abstract}

Keywords: gluten-free products; alternative cereal; food stability; meat products; acceptability; roasting.

Practical Application: Kibbeh formulations with millet flour can be a good alternative for gluten-free diet.

\section{Introduction}

Millet (Pennisetum glaucum (L.) R. Br.) is a small cereal with seeds of 1.2-1.8 $\mathrm{mm}$ in diameter and a light brown-to-brick red colored seed coat with an undulated surface. Millet is a word derived from "mille", which signifies a thousand grains. The major millet species in the world is pearl millet (Pennisetum glaucum (L.) R. Br.), followed by foxtail, proso and finger millet (Shahidi \& Chandrasekara, 2013).

Pearl millet is a food that supplies a major proportion of calories and protein to large segments of populations in the semi-arid tropical regions of Africa and Asia (O'Kennedy et al., 2006). Recombinant DNA technology is a powerful tool that has been recently used to enhance the gene pools of sorghum and pearl millet crops, which are regarded as important crops, particularly in countries like Africa (O’Kennedy et al., 2006).

Millet is a gluten-free and low-cost cereal (approximately $40 \%$ lower than the price of corn), which is resistant to drought and nutrient-poor soils (Gomes et al., 2008). In 2011, the global millet production was about 27.5 million tones (Food and Agriculture Organization, 2015). Countries in Africa and Asia produced $56 \%$ and $41 \%$ of the total world production, respectively (Shahidi \& Chandrasekara, 2013).

In years 2003/2004 millet cultivation area in Brazil corresponded to four million hectares, and the estimative to years 2008/2009 were about five million hectares (Brasil, 2008). There is no current data of millet production in Brazil because it is not commonly used for human feeding despite represents an important ingredient for feeding confined cattle, poultry and pork (Brasil, 2008). So, it is considered an underutilized cereal (Suma \& Urooj, 2014), even in the agroecological systems where they grow (Shahidi \& Chandrasekara, 2013).

Millet is a superior cereal with regard to nutritional quality and presents several health benefits (Krishnan et al., 2011). It is a rich source of dietary fiber, calcium, oleic acid (25\%) and linoleic acid (46\%) (Rooney, 1978) and of phytochemicals with nutraceutical potential (Malleshi \& Hadimani, 1999). Moreover, millet is a potent source of antioxidants, due to its phenolic content (Dykes \& Rooney, 2006; Shahidi \& Chandrasekara, 2013) and is a staple food substitute for celiac patients who require gluten-free cereal (Shahidi \& Chandrasekara, 2013).

Due to its nutritional characteristics and low cost, there is increased interest in millet due to its health benefits, hypoglycemic characteristics (Lakshmi Kumari \& Sumathi, 2002) and due to the antimicrobial and antioxidant activities of its polyphenols (Chethan \& Malleshi, 2007). Moreover, as millet does not contain gluten and is known for its low carbohydrate concentration and low glycemic index (Singh et al., 2010; Suma \& Urooj, 2014), some authors has studied its viability in bakery products such as breads, biscuits and pasta (Rathi et al., 2004; Saha et al., 2011; Schoenlechner et al., 2013), aiming to replace whole-wheat flour with millet flour. The acceptability of the foods developed with millet flour, such as biscuit dough and breads, is reported to be very good (Saha et al., 2011; Schoenlechner et al., 2013). 
Unfortunately, no meat products that employ the use of millet or millet flour have been described in the literature. The evolution of nutritional and eating habits throughout human history has led to the modern custom of eating snacks (Danski, 2008). Despite originally being a Turkish cuisine, kibbeh is one of the most famous meat snack foods in Brazil. Kibbeh is an industrialized meat product, obtained from beef or lamb, which is minced, added to whole-wheat flour, spices and other ingredients (Brasil, 2000) and is usually commercialized raw (kibbeh nayeh), deep-fried or baked. However, in its original formulation, whole-wheat flour is an essential ingredient and this product should not be consumed by celiac patients.

Thus, the aim of this study was to develop different kibbeh formulations using millet flour and evaluate their nutritional, sensorial and technological quality following freeze storage (90 days at $-18^{\circ} \mathrm{C}$ ), in order to replace whole-wheat flour and provide novel and alternative gluten-free products.

\section{Material and methods}

\subsection{Material and reagents}

Pearl millet (Pennisetum glaucum (L.) R. Br.) - ADR 7010 cultivar, a hybrid with the attributes of both straw and grain and great productive potential (50 bags ha-1), was kindly provided from the "Sementes Adriana" Company (Mato Grosso, Brazil). Other ingredients used to prepare kibbeh (ground beef, whole-wheat flour and spices) were purchased at a local market. All other chemical reagents used in this study were of analytical grade.

\section{Millet flour}

Seeds (Pearl millet) were ground using a mill (MCS 280- 5 hp Vieira, Tatuí, SP, Brazil) in sieves with a 3-mm particle size under continuous suction. The millet flour was stored $\left(-22^{\circ} \mathrm{C}\right)$ until analysis. Millet flour was roasted or hydrated to yield two types of flour; roasted millet flour (RM) and wet millet flour (WM). RM was prepared using $50 \pm 0.1 \mathrm{~g}$ of millet flour, roasted on a domestic stove oven at $240{ }^{\circ} \mathrm{C}$ with stirring during five minutes. WM was prepared using $30 \mathrm{~mL}$ of boiling water added to $25 \pm 0.1 \mathrm{~g}$ of millet flour during ten minutes. The excess of water was removed using a domestic sieve. The same hydration procedure was used to hydrate the wet whole-wheat flour, which was applied as a control (CT) for the kibbeh samples.

\section{Kibbeh formulation and manufacturing}

Kibbeh samples were formulated according to the Technical Regulation of Kibbeh Identification and Quality (Brasil, $2000,2001)$. The formulations were prepared as described by Degáspari et al. (2002), with some modifications (Table 1). TM and WM were used to replace the whole-wheat flour in the original kibbeh formulations. All ingredients used in these processes (Table 1) were homogenized for ten minutes and the samples were then stored frozen for 90 days $\left(\mathrm{T}_{90}\right)$ $\left(-18^{\circ} \mathrm{C}\right)$. Chemical, color and texture profile analysis were performed before and after storage for 90 days. Before the tests, samples were previously defrosted and cooked (fried and baked). Fried kibbeh (FRM and FWM) were portioned
$(20 \pm 0.1 \mathrm{~g})$ and deep fried in soybean oil $\left(120-130^{\circ} \mathrm{C}\right)$ for three minutes until reaching a characteristic color (golden brown). The baked kibbeh samples (BRM and BWM) were placed in inox pans $(30 \times 20 \mathrm{~cm})$ and baked in an electric oven $\left(180^{\circ} \mathrm{C}\right)$ for 35 minutes. As such, we obtained the following samples: Baked kibbeh with roasted millet flour (BRM); Fried kibbeh with roasted millet flour (FRM); Baked kibbeh with wet millet flour (BWM) and Fried kibbeh with wet millet flour (FWM). Water activity analysis, microbiology assay and TBARS analyses were performed in the defrosted samples following 90 days of storage $\left(-18^{\circ} \mathrm{C}\right)$.

\section{Chemical analysis}

Three samples were randomly separated from each kibbeh sample (FRM, FWM, BRM and BWM) for the nutritional composition analysis. Moisture, ashes and protein content were determined according to Association of Official Analytical Chemists (1990) methods. Protein content (total nitrogen content) was determined using the Micro-Kjeldahl method with a conversion factor of 6.25; the digestible carbohydrates content was determined by the difference and total lipids extracted in methanol: chloroform (Bligh \& Dyer, 1959). Dietary fiber was determined according to the methodology described by Prosky et al. (1988). Water activity $\left(\mathrm{a}_{\mathrm{w}}\right)$ was measured during 90 days of storage using the Aqualab system (Decagon, model CX-2, Devices Inc., Pullman WA, USA) at room temperature $\left(25^{\circ} \mathrm{C}\right)$.

\section{Microbiological analyses}

The ingredients used in the kibbeh formulations, fried and baked kibbeh samples were submitted to microbiological analysis to control their sanitary quality, according to Resolution RDC number 12 of the National Health Surveillance Agency (Brasil, 2001). Analyses were performed in triplicate as described by the Compendium of Methods for the Microbiological Examination of Foods (Downes \& Ito, 2001).

Table 1. Kibbeh Formulation (g.100g-1).

\begin{tabular}{cccc}
\hline & \multicolumn{3}{c}{ Kibbeh Samples $^{\mathrm{a}}$} \\
\hline Ingredients & CT & RM & WM \\
\hline Beef & 85.00 & 85.00 & 85.00 \\
Whole-wheat & 8.50 & - & - \\
flour & & - & 8.50 \\
Wet millet flour & - & 8.50 & - \\
Roasted millet & - & & \\
flour & & 0.34 & 0.34 \\
Fresh garlic & 0.34 & 0.70 & 0.70 \\
Fresh parsley & 0.70 & 1.36 & 1.36 \\
Fresh mint & 1.36 & 1.40 & 1.40 \\
Salt & 1.40 & 2.70 & 2.70 \\
Soybean oil & 2.70 & 100.00 & 100.00 \\
Total (g) & 100.00 & & \\
\hline
\end{tabular}

${ }^{a}$ All samples were fried (F) or baked (B) for the analysis. CT: Control (whole-wheat flour). RM: Roast Millet Flour. WM: Wet Millet Flour. 


\section{Color and texture analyses}

The samples were defrosted, except $\mathrm{T}_{0}$, and cooked (fried or baked) prior to starting color and the texture analysis. Color parameters were analyzed using a colorimeter (HunterLab, ColorQuest II, Reston, England) with Universal Software 4.10 on the CIELAB system. The color measurements were performed five times in different places for each sample. The texture parameters was evaluated using a texturometer (Stable MicroSystems, TA-XTplus, Surrey, UK) with SMS-P/5 aluminum probe under a uniaxial force up to $70 \%$ strain, using cylindrical specimens of size $2 \times 2 \mathrm{~cm}$, with $2 \mathrm{~mm} \mathrm{~s}^{-1}$ pre-test speed, $1 \mathrm{~mm} \mathrm{~s}^{-1}$ test speed, and $10 \mathrm{~mm} \mathrm{~s}^{-1}$ post-test speed. Hardness, defined as the maximum peak force required to compress the sample, was evaluated and expressed in Newtons (N). Seven measurements were recorded for each sample.

\section{Lipid oxidation}

Lipid oxidation was assessed by measuring the thiobarbituric acid reactive substances (TBARS), according to the methodology described by Wyncke (1970) with some adaptations proposed by Capitani et al. (2009). TBARS concentration was measured after the storage time (90 days) after defrosting the samples. A calibration curve was constructed using TEP solutions of concentrations varying from 0 to $1.25 \mathrm{mg} \cdot \mathrm{mL}^{-1}$. The TBARS concentration was expressed as mg MDA. $\mathrm{kg}^{-1} \mathrm{kibbeh}$.

\section{Sensory evaluation}

Sensorial analysis was conducted in two steps. First, the samples were evaluated using the preference test based on a nine-point hedonic scale ( 1 = extremely dislike to $9=$ extremely like) (Meilgaard et al., 2007). Global appearance characteristics were evaluated and the acceptability index (AI) of the kibbeh samples was calculated as $A I(\%)=($ Average score $\div$ highest score $)$ $x 100$ (Teixeira et al., 1987). The sensorial test was applied in individual cabins illuminated by red lamps. Fresh kibbeh samples (fried and baked) were served on individual plates $(20 \pm 0.1 \mathrm{~g}$ ), coded with a three-digit number, following a randomized block design, to 57 untrained volunteer panelists from the University staff. Panelists signed an approved informed consent form regarding the Ethics Protocols of Research involving Human Tests before starting the test (Research Ethics Committee of Federal University of Goiás - n ${ }^{\circ}$ 209/2011). Panelists aged between 20 and 64 years were selected to taste and analyse the samples. Were used as exclusion criteria; diabetes, allergies to the ingredients of the kibbeh and diseases that could interfere with taste and/or olfactory sensitivity. The second step of the study was carried out in a supermarket during three days using potential consumers $(n=92)$, aiming to evaluate the acceptability of the potential consumers. The baked kibbeh samples (CT, BRM and BWM) were freshly prepared using the same conditions described above and heated $\left(35^{\circ} \mathrm{C}\right)$ before the consumer test. Samples were evaluated using the preference test, based on a nine-point hedonic scale ( 1 = extremely dislike to $9=$ extremely like) (Meilgaard et al., 2007); taste, texture, and global appearance characteristics were evaluated.

\section{Statistical analysis}

The data were tested for normality (Shapiro-Wilk test), then submitted to analysis of variance (two-way ANOVA), followed by Bonferroni post-tests, to compare the replicate means by samples. Samples from the two time intervals $\left(\mathrm{T}_{0}\right.$ and $\left.\mathrm{T}_{90}\right)$ were compared by repeated ANOVA measurements. Chemical and sensorial results were submitted to analysis of variance (one-way ANOVA). All statistical analyses and graphs were made using GraphPad Prism software (version 5.00Trial, Targetware Informática Ltda, São Paulo, Brazil).

\section{Results}

Millet flour maintained the same amount $(\mathrm{p}>0.05)$ of dietary fiber $\left(4.06 \pm 0.11 \mathrm{~g} .100 \mathrm{~g}^{-1}\right)$ and protein $\left(20.60 \pm 2.21 \mathrm{~g} .100 \mathrm{~g}^{-1}\right)$

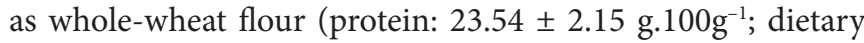
fiber: $\left.3.21 \pm 0.06 \mathrm{~g} .100 \mathrm{~g}^{-1}\right)$. The average chemical composition of kibbeh samples prepared with millet flour (RM or WM) were $55.91 \pm 2.04 \mathrm{~g}$ moisture, $12.51 \pm 1.76 \mathrm{~g}$ lipids and $2.80 \pm 0.27 \mathrm{~g}$ ashes. $100 \mathrm{~g}^{-1}$ of sample. These results were not different $(\mathrm{p}<0.05)$ of the kibbeh prepared whole-wheat flour (CT), that presented $56.06 \pm 0.98 \mathrm{~g}$ moisture; $10.06 \pm 0.73 \mathrm{~g}$ lipids and $1.34 \pm 0.13 \mathrm{~g}$ ashes. $100 \mathrm{~g}^{-1}$ of sample.

The water activity parameter did not present significant changes following 90 days of storage and the average results ranged between 0.96 and 0.99 . While the kibbehs had high water activity values, microbiological analysis showed satisfactory sanitary conditions for all of the kibbeh samples and were below the limits established by the Brazilian sanitary legislation $\left(<10\right.$ UFC. $\left.{ }^{-1}\right)$, representing accordance with the law of good manufacturing practices (Brasil, 2001).

After 90 days of storage $\left(\mathrm{T}_{0}\right.$ and $\left.\mathrm{T}_{90}\right)$ significant differences $(\mathrm{p}<0.05)$ in the color parameters of the kibbeh samples were observed for the $L^{*}, a^{*}, b^{*}$ and Chroma (Table 2). Reductions in the lightness $\left(L^{*}\right)$ and redness $\left(a^{*}\right)$ parameters were recorded following 90 days of storage. FRM and CT fried samples showed a greater reduction in the $L^{*}$ parameter $\left(\Delta L^{*} \sim 24.5\right.$ and 20.7, respectively), indicating increased opacity during storage.

The texture analysis showed significant differences $(\mathrm{p}<0.05)$ in hardness for almost samples following the storage time (90 days), except for the Control fried (Fried kibbeh with whole-wheat flour - CT fried) (Figure 1). Initially, samples prepared with roasted millet flour (FRM and BRM) were harder than other samples and this may be due to the lower water content in the RM. However freeze storage reduced the hardness $(\mathrm{N})$ in almost samples $(\mathrm{p}<0.05)$, except for the Control fried (Fried kibbeh with whole-wheat flour - CT fried) and was more expressive for the FWM sample $\left(\mathrm{T}_{0}=132.7 \pm 11.7 ; \mathrm{T}_{90}=72.7 \pm 4.6\right)$. The CT baked sample did not differ significantly ( $\mathrm{p}>0.05)$ from the CT fried after 90 days of storage.

The data for the oxidative stability of the kibbeh samples (Figure 2) reveal that the CT sample presented an increased TBARS concentration following 90 days of storage $\left(-18^{\circ} \mathrm{C}\right)$, where the TBARS concentration significantly increased $(\mathrm{p}<0.05)$ during freezing for 90 days $\left(\mathrm{T}_{0}\right.$ and $\left.\mathrm{T}_{90}\right)$ at $-18{ }^{\circ} \mathrm{C}$. When ascorbic acid was added to the control sample $(0.01 \%)$, values of TBARS were not lowered when compared to those of the CT (without ascorbic 
Table 2. Color Parameters $\left(L^{*}, a^{*}, b^{*}\right.$, and Chroma) of Fresh Kibbeh $\left(\mathrm{T}_{0}\right)$ and following 90 days of freeze storage ( $\left.\mathrm{T}_{90}\right)$, based on the CIELAB System. Results were expressed as medium \pm SD $(n=5)$.

\begin{tabular}{|c|c|c|c|c|c|c|c|c|}
\hline \multicolumn{9}{|c|}{ Color parameters } \\
\hline & \multicolumn{2}{|c|}{$L^{*}$} & \multicolumn{2}{|c|}{$a^{*}$} & \multicolumn{2}{|c|}{$\mathrm{b}^{*}$} & \multicolumn{2}{|c|}{ Chroma } \\
\hline Samples & $\mathrm{T}_{0}$ & $\mathrm{~T}_{90}$ & $\mathrm{~T}_{0}$ & $\mathrm{~T}_{90}$ & $\mathrm{~T}_{0}$ & $\mathrm{~T}_{90}$ & $\mathrm{~T}_{0}$ & $\mathrm{~T}_{90}$ \\
\hline CT fried & $46.6 \pm 0.1$ & $25.9 \pm 2.0$ & $26.3 \pm 0.3$ & $11.3 \pm 0.5$ & $16.1 \pm 1.8$ & $18.5 \pm 1.3$ & $30.8 \pm 1.2$ & $21.7 \pm 1.1$ \\
\hline CT baked & $50.4 \pm 0.1^{\mathrm{a}}$ & $38.6 \pm 2.4^{\mathrm{a}}$ & $24.9 \pm 0.1^{\mathrm{a}}$ & $6.3 \pm 0.4^{\mathrm{a}}$ & $7.1 \pm 0.6^{\mathrm{a}}$ & $17.9 \pm 1.2$ & $25.9 \pm 0.1^{\mathrm{a}}$ & $19.1 \pm 1.2^{\mathrm{a}}$ \\
\hline FWM & $36.1 \pm 0.1^{\mathrm{a}, \mathrm{b}}$ & $21.6 \pm 3.0^{\mathrm{a}, \mathrm{b}}$ & $36.0 \pm 0.1^{\mathrm{a}, \mathrm{b}}$ & $17.7 \pm 1.1^{\mathrm{a}, \mathrm{b}}$ & $44.1 \pm 0.6^{\mathrm{a}, \mathrm{b}}$ & $28.9 \pm 1.4^{\mathrm{a}, \mathrm{b}}$ & $57.0 \pm 1.8^{\mathrm{a}, \mathrm{b}}$ & $33.9 \pm 1.2^{\mathrm{a}, \mathrm{b}}$ \\
\hline FRM & $47.7 \pm 0.5^{\mathrm{a}, \mathrm{b}, \mathrm{c}}$ & $23.2 \pm 2.4^{\mathrm{b}, \mathrm{c}}$ & $30.9 \pm 0.2^{\mathrm{a}, \mathrm{b}, \mathrm{c}}$ & $11.8 \pm 0.8^{\mathrm{b}, \mathrm{c}}$ & $31.2 \pm 0.9^{\mathrm{a}, \mathrm{b}, \mathrm{c}}$ & $17.9 \pm 1.1^{\mathrm{c}}$ & $43.9 \pm 0.8^{\mathrm{a}, \mathrm{b}, \mathrm{c}}$ & $21.5 \pm 1.4^{\mathrm{b}, \mathrm{c}}$ \\
\hline
\end{tabular}

Different letters in the same columns represent significant difference ( $<<0.05)$ between the samples. CT fried: Control fried (Fried kibbeh with whole wheat flour ). CT baked: Control baked (Baked kibbeh with whole wheat flour). FWM: Fried kibbeh with wet millet flour. FRM: Fried kibbeh with roasted millet flour. BWM: Baked kibbeh with wet millet flour. BRM: Baked kibbeh with roasted millet flour.

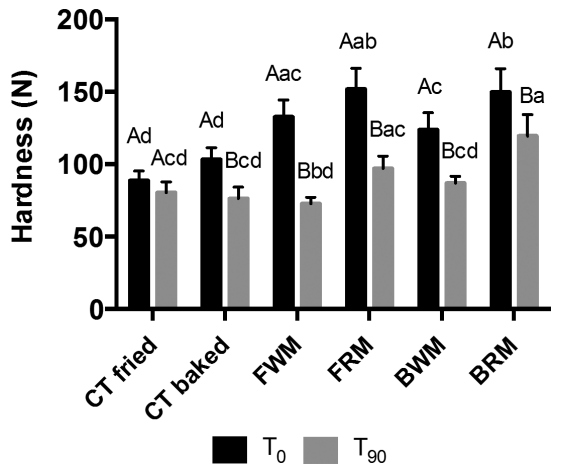

Figure 1. Hardness (N) of the baked (B) or fried (F) kibbeh samples at the beginning $\left(\mathrm{T}_{0}\right)$ and after 90 days of freeze storage $\left(\mathrm{T}_{90}\right)$. Bars represent means $(n=7+S D)$. Bars labelled with different letters represents statistical difference $(\mathrm{p}<0.05)$ : Capital letter: comparison between samples at $\mathrm{T}_{0}$ or $\mathrm{T}_{90}$ of storage, for same kibbeh formulation; Small letter: comparison among all kibbeh formulations at same storage time. CT fried: Control (Fried kibbeh with whole-wheat flour), CT baked: Control ${ }_{2}$ (Baked kibbeh with whole-wheat flour), FWM: Fried kibbeh with wet millet flour, FRM: Fried kibbeh with roasted millet flour, BWM: Baked kibbeh with wet millet flour, BWM: Baked kibbeh with roasted millet flour.

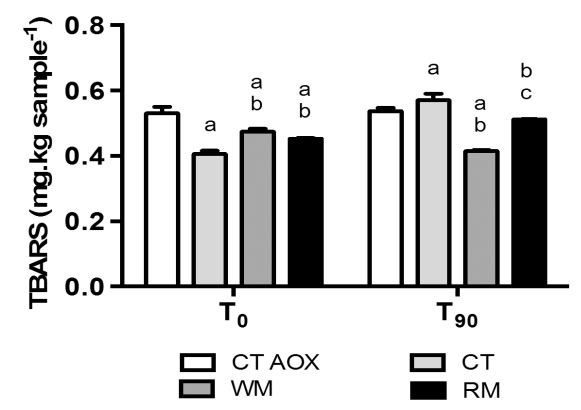

Figure 2. Lipid oxidation of the samples at the beginning $\left(\mathrm{T}_{0}\right)$ and after 90 days of freeze storage $\left(\mathrm{T}_{90}\right)$, expressed as mg MDA.kg ${ }^{-1}$ sample. Bars represent mean $(n=3) \pm$ SD. Bars followed by different letters represents statistical difference $(\mathrm{p}<0.05)$ between samples. CT AOX: kibbeh prepared with whole whole-wheat flour and with ascorbic acid (0.01\% p:v); CT: kibbeh prepared with whole-wheat flour and without antioxidant; WM: kibbeh prepared with wet millet flour; RM: kibbeh prepared with roasted millet flour. acid) and the millet samples (Figure 2). Samples prepared with millet flour (RM and WM), showed lower TBARS concentrations compared to the CT after 90 days of storage $(\mathrm{p}<0.05)$.

There were no statistical differences among the samples ( $p>0.05)$ when the acceptability indices (AI \%) were analyzed. Untrained panelists preferred the baked CT sample (AI $=83 \%)$, followed by BRM (78.9\%) and fried CT (75.4\%). When potential consumers evaluated the baked kibbeh samples in the supermarket, no differences $(\mathrm{p}<0.05)$ were found between the CT sample and the other samples (BRM and BWM). All attributes received average grades of above six, indicating good acceptability compared with conventional preparations (CT).

\section{Discussion}

The nutritional composition of kibbehs prepared with millet flour were not different to the nutritional contents of the CT kibbeh samples. However, lipids content were slightly higher in the kibbehs prepared with millet flour and it could be explained mainly by the influence of the cooking procedure (Krishnan et al., 2011; Miyagusku, 2006), since all preparations used the same ingredients, with the exception of the millet. Despite these results, all kibbeh samples prepared with millet flour could be classified as a "source" and as a "food with high amount" of fiber and proteins (Brasil, 2012) due to their elevated amount of fiber (average $4.0 \mathrm{~g} .100 \mathrm{~g}^{-1}$ ) and proteins (average $20.6 \mathrm{~g} .100 \mathrm{~g}^{-1}$ ). Thus, millet flour could represent an alternative to substitute whole-wheat flour, ensuring the protein and dietary fiber intake for individuals with celiac disease.

In this study, we did not use sodium erythorbate to preserve or to fix the red color of the meat; the color of kibbehs is usually brown or dark, and we observed the reduction in the lightness $\left(L^{*}\right)$ and redness $\left(a^{*}\right)$ parameters during 90 days of storage. Usually, freeze storage $\left(-18^{\circ} \mathrm{C}\right)$ of beef samples reduced colorimetric parameters over storage time (Fernández et al., 2007; Scramlin et al., 2010). The excess of metamyoglobin, formed during freeze storage, could reduce the redness parameter $\left(a^{*}\right)$ and, consequently, increase $b^{*}$ values (Martínez et al., 2006; Valencia et al., 2008). However, the $b^{\star}$ parameter was significantly reduced in the FRM and BWM samples and these results did not corroborate with the literature. The changes in the lightness $\left(L^{*}\right)$ and in the redness $\left(a^{*}\right)$ values may not indicate loss in 
the quality parameters, unless the consumer disapproves this parameter when buying these products. However, there were no sensorial differences when color was analyzed.

Different cooking methods (Apple et al., 1999) influenced the texture of the food products; however, no differences between the hardness $(\mathrm{N})$ of the baked or fried kibbeh were found in this study. According to the sensorial analysis, panelists related that the kibbeh samples prepared with RM flour were crisper and harder than the other preparations and the texture profiles confirm these findings. Following storage (90 days), the kibbeh samples demonstrated reduced hardness due to ice crystal formation by the meat products during freeze storage, which promotes the output of intracellular water by osmosis and causes modification in texture parameters after the defrosting process (Ordónez, 2005). Considering formulations containing millet, Baked kibbeh (BWM and BRM) showed lower reduction of hardness than fried kibbeh (FWM and BRM) in relation to initial time and after storage under freezing. Despite of kibbeh containing whole-wheat flour (CT baked and CT fried) have showed lower hardness than kibbeh containing millet flour, consumers did not detected differences in the texture, because sensory acceptability showed no statistical differences among the samples ( $p>0.05)$ when the acceptability indices (AI \%) were analyzed.

Ascorbic acid (applied at the $0.01 \%$ level) may have acted as a pro-oxidant in the CT samples, resulting in increased TBARS concentrations following storage. Moreover, antioxidant efficiency depends on the level of the antioxidant in the matrix composition (Capitani et al., 2013). In the other samples prepared with millet flour (RM and WM), TBARS concentration remained below the limits $(<0.51 \mathrm{mg}$ MDA.kg-1 kibbeh) during 90 days of storage, and this would suggest that there was no development of a rancid flavored (0.5 to $2.0 \mathrm{mg}$ MDA.kg-1) sample (Gray \& Pearson, 1984)

Some studies have reported antioxidant and potent radical scavenging activity in millet grains (Hegde et al., 2005; Dykes \& Rooney, 2006; Amadou et al., 2013a; Shahidi \& Chandrasekara, 2013; Pradeep \& Sreerama, 2015) and the in vitro antioxidant activity of millet is usually attributed to its phenolic content, represented by vanillic and ferulic acids (Pradeep \& Sreerama, 2015). More recently, Zhang \& Liu (2015), observed that foxtail millet extracts inhibited the growth of human breast and liver cancer cells in culture. While the antioxidant activity and phenolic content of samples were not evaluated in this study, it is important to note that the presence of millet flour maintained TBARS levels lower during 90 days of storage. The antioxidant properties of millet grains could also provide health benefits to humans (Hegde et al., 2005; Amadou et al., 2013b) acting on management of cardiovascular, geriatric diseases and cancers (Zhang \& Liu, 2015). The use of millet as a nutraceutical and specialty food is warranted (Shahidi \& Chandrasekara, 2013) and should be studied in humans' subjects to observe the impact of this food on health.

Our results corroborate with other studies reporting good acceptability of products formulated with millet flour (Krishnan et al., 2011; Saha et al., 2011; Schoenlechner et al., 2013). According to Singh et al. (2012), millets can replace wheat in the bread to some extent with good acceptability. However, the addition of millet flour to wheat bread caused a decline in bread quality due to the reduction in the final gluten content (Schoenlechner et al., 2013), which is essential to breads.

\section{Conclusions}

Roasted or wet millet flour could be used into kibbeh formulations to replace whole-wheat flour without affecting their nutritional and technological properties. Kibbeh formulations with roasted or wet millet flour presented good acceptability and showed oxidation stability measured by TBARS concentration during storage for 90 days at $-18{ }^{\circ} \mathrm{C}$. So, millet holds a huge potential for food production and, in particular, for replacing whole-wheat flour. As such, it can be used in several food products, such as kibbeh, making a valuable contribution to a healthy diet, particularly in individuals with celiac disease.

\section{Acknowledgements}

We would like to thank the Postgraduate Program in Nutrition and Health of Federal University of Goiás for their financial support and the Adriana Seed ${ }^{\circledR}$ Company for the supply of millet.

\section{References}

Amadou, I., Le, G. W., \& Shi, Y. H. (2013b). Evaluation of antimicrobial, antioxidant activities and nutritional values of fermented foxtail millet extracts by Lactobacillus paracasei Fn032. International Journal of Food Properties, 16(6), 1179-1190. http://dx.doi.org/10. 1080/10942912.2011.579673.

Amadou, I., Le, G.W., Amza, T., Sun, J., \& Shi, Y. H. (2013a). Purification and characterization of foxtail millet-derived peptides with antioxidant and antimicrobial activities. Food Research International, 51(1), 422428. http://dx.doi.org/10.1016/j.foodres.2012.12.045.

Apple, J. K., Rakes, L. K., \& Watson, H. (1999). Cooking and shearing methodology effects on warmer-Bratzler shear force values of pork. Journal of Muscle Foods, 10(3), 269-277. http://dx.doi. org/10.1111/j.1745-4573.1999.tb00402.x.

Association of Official Analytical Chemists - AOAC (1990). Official methods of analysis. Washington, DC: AOAC.

Bligh, E. G., \& Dyer, W. J. (1959). A rapid method of total lipid extraction and purification. Canadian Journal of Biochemistry and Physiology, 37, 911-917. http://dx.doi.org/10.1139/o59-099. PMid:13671378

Brasil, Agência Nacional de Vigilância Sanitária - ANVISA. (2001, January 1). Resolução RDC no 12, de 02 de janeiro de 2001. Aprova o Regulamento Técnico sobre padróes microbiológicos para alimentos. Diário Oficial da República Federativa do Brasil. Retrieved from http://portal.anvisa.gov.br/wps/wcm/connect/a47bab8047458b909 541d53fbc4c6735/RDC_12_2001.pdf?MOD=AJPERES

Brasil, Ministério da Agricultura, Pecuária e Abastecimento, Empresa Brasileira de Pesquisa Agropecuária - EMBRAPA, Centro Nacional de Pesquisa de Milho e Sorgo. (2008). A cultura do Milheto. Retrieved from http://www.infoteca.cnptia.embrapa.br/infoteca/bitstream/ doc/491152/1/Milheto.pdf

Brasil, Ministério da Agricultura, Secretaria Nacional de Defesa Agropecuária. (2000). Regulamento técnico de identidade e qualidade de Kibbeh. Brasília, DF: MAPA. Retrieved from http://www.cfmv.org.br/portal/ legislacao/outras_normas/instrucao_normativa_020_MAA.htm

Brasil, Ministério da Saúde, Secretaria de Vigilância Sanitária. (2012). $R D C n^{\circ} 54$, de 12 de novembro de 2012. Dispóe sobre o regulamento 
técnico sobre informação nutricional complementar. Retrieved http:// portal.anvisa.gov.br/wps/wcm/connect/630a98804d7065b981f1e1 c116238c3b/Resolucao+RDC+n.+54_2012.pdf?MOD=AJPERES

Capitani, C. D., Carvalho, A. C., Rivelli, D. P., Barros, S. B. M., \& Castro, I. A. (2009). Evaluation of natural and synthetic compounds according to their antioxidant activity using a multivariate approach. European Journal of Lipid Science and Technology, 111(11), 1090-1099. http:// dx.doi.org/10.1002/ejlt.200800215.

Capitani, C. D., Hatano, M. K., Marques, M. F., \& Castro, I. A. (2013). Effects of optimized mixtures containing phenolic compounds on the oxidative stability of sausages. Food Science And Technology International = Ciencia Y Tecnología De Los Alimentos Internacional, 19(1), 69-77. http://dx.doi.org/10.1177/1082013212442184. PMid:23014857

Chethan, S., \& Malleshi, N. G. (2007). Finger millet polyphenols: characterization and their nutraceutical potential. American Journal of Food Technology, 2(7), 582-592. http://dx.doi.org/10.3923/ ajft.2007.582.592.

Danski, M. T. R. (2008). Historia y alimentacion: el advent del fast food en Curitiba. Historia Actual Online, 17(1), 19-29.

Degáspari, C. H., Piccolomini, A. F., \& Picanço, M. C. A. (2002). Desenvolvimento de produto à base de fibras de beterraba (Beta vulgaris variedade açucareira). Alimentos e Nutrição, 13(1), 103-115.

Downes, F. P., \& Ito, K. (Eds.). (2001). Compendium of methods for the microbiological examination offoods (4th ed.). Washington: American Public Health Association. http://dx.doi.org/10.2105/9780875531755.

Dykes, L., \& Rooney, L. W. (2006). Review: sorghum and millet phenols and antioxidants. Journal of Cereal Science, 44(3), 236-251. http:// dx.doi.org/10.1016/j.jcs.2006.06.007.

Fernández, P. P., Sanz, P. D., Molina-García, A. D., Otero, L., Guignon, B., \& Vaudagna, S. R. (2007). Conventional freezing plus high pressurelow temperature treatment: Physical properties, microbial quality and storage stability of beef meat. Meat Science, 77(4), 616-625. http://dx.doi.org/10.1016/j.meatsci.2007.05.014. PMid:22061950

Food and Agriculture Organization - FAO. (2015). FAO Statistical Databases. Retrieved from http://www.fao.org

Gomes, P. C., Rodrigues, M. P., Albino, L. F. T., Rostagno, H. S., Gomes, M. F. M., Mello, H. H. C., \& Brumano, G. (2008). Determinação da composição química e energética do milheto e sua utilização em rações para frangos de corte de 1 a 21 dias de idade. Revista Brasileira de Zootecnia, 37(9), 1617-1621. http://dx.doi.org/10.1590/ S1516-35982008000900013.

Gray, J. I., \& Pearson, A. M. (1984). Cured meat flavor. Advances in Food Research, 29, 1-86. http://dx.doi.org/10.1016/S0065-2628(08)60055-5.

Hegde, P. S., Rajasekaran, N. S., \& Chandra, T. S. (2005). Effects of the antioxidant properties of millet species on oxidative stress and glycemic status in alloxan-induced rats. Nutrition Research, 25(12), 1109-1120. http://dx.doi.org/10.1016/j.nutres.2005.09.020.

Krishnan, R., Dharmaraj, U., Sai Manohar, R., \& Malleshi, N. G. (2011). Quality characteristics of biscuits prepared from finger millet seed coat based composite flour. Food Chemistry, 129(2), 499-506. http:// dx.doi.org/10.1016/j.foodchem.2011.04.107.

Lakshmi Kumari, P., \& Sumathi, S. (2002). Effect of consumption of finger millet on hyperglycemia in non-insulin dependent diabetes mellitus (NIDDM) subjects. Plant Foods for Human Nutrition, 57(3-4), 205-213. http://dx.doi.org/10.1023/A:1021805028738. PMid:12602929

Malleshi, N. G., \& Hadimani, N. A. (1999). Nutritional and technological characteristics of small millets and preparation of value added products from them. In K. W. Riley, S. C. Gupta, A. Seetharam \& J.
N. Mushonga (Eds.), Advances in small millets (pp. 270-287). New Delhi: Oxford/IBH publishing Company.

Martínez, L., Djenane, D., Cilla, I., Beltrán, J. A., \& Roncáles, P. (2006). Effect of varying oxygen concentrations on the shelf-life of fresh pork sausages packaged in modified atmosphere. Food Chemistry, 94(2), 219-225. http://dx.doi.org/10.1016/j.foodchem.2004.11.007.

Meilgaard, M., Civille, G. V., \& Carr, B. T. (2007). Sensory evaluation techniques (4th ed.). Florida, USA: CRC Press. 448 p.

Miyagusku, L. (2006). Rotulagem de alimentos segundo ANVISA: composição de carnes in natura. In C. J. C. Castillo (Ed.), Qualidade de carne (pp. 209-219). São Paulo: Varela.

O'Kennedy, M. M., Grootboom, A., \& Shewry, P. R. (2006). Harnessing sorghum and millet biotechnology for food and health. Journal of Cereal Science, 44(3), 224-235. http://dx.doi.org/10.1016/j.jcs.2006.08.001.

Ordónez, J. A. (2005). Tecnologia de alimentos: componentes dos alimentos e processos. Porto Alegre: Artmed.

Pradeep, P. M., \& Sreerama, Y. N. (2015). Impact of processing on the phenolic profiles of small millets: evaluation of their antioxidant and enzyme inhibitory properties associated with hyperglycemia. Food Chemistry, 169, 455-463. http://dx.doi.org/10.1016/j. foodchem.2014.08.010. PMid:25236251

Prosky, L., Asp, N. G., Schewizer, T. F., DeVries, J. W., \& Furda, I. (1988). Determination of insoluble, soluble, and total dietary fibre in foods and food products: interlaboratory study. Journal - Association of Official Analytical Chemists, 71, 1017-1023. PMid:2853153.

Rathi, A., Kawatra, A., \& Sehgal, S. (2004). Influence of depigmentation of pearl millet (Pennisetum glaucum L.) on sensory attributes, nutrient composition, in vitro protein and starch digestibility of pasta. Food Chemistry, 85(2), 275-280. http://dx.doi.org/10.1016/j. foodchem.2003.06.021.

Rooney, L. W. (1978). Sorghum and pearl millet lipids. Cereal Chemistry, 55(5), 584-590.

Saha, S., Gupta, A., Singh, S. R. K., Bharti, N., Singh, K. P., Mahajan, V., \& Gupta, H. S. (2011). Compositional and varietal influence of finger millet flour on rheological properties of dough and quality of biscuit. LWT - Food Science and Technology, 44(3), 616-621. http:// dx.doi.org/10.1016/j.lwt.2010.08.009.

Schoenlechner, R., Szatmari, M., Bagdi, A., \& Tömösközi, S. (2013). Optimization of bread quality produced from wheat and proso millet (Panicum miliaceum L.) by adding emulsifiers, transglutaminase and xylanase. LWT - Food Science and Technology, 51(1), 361-366. http://dx.doi.org/10.1016/j.lwt.2012.10.020.

Scramlin, S. M., Newman, M. C., Cox, R. B., Sepe, H. A., Alderton, A. L., O'Leary, J., \& Mikel, W. B. (2010). Effects of oregano oil brine enhancement on quality attributes of beef longissimus dorsi and semimembranosus muscles from various age animals. Journal of Food Science, 75(2), S89-S94. http://dx.doi.org/10.1111/j.17503841.2009.01459.x. PMid:20492261

Shahidi, F., \& Chandrasekara, A. (2013). Millet grain phenolics and their role in disease risk reduction and health promotion: a review. Journal of Functional Foods, 5(2), 570-581. http://dx.doi.org/10.1016/j. jff.2013.02.004.

Singh, K. P., Mishra, A., \& Mishra, H. N. (2012). Fuzzy analysis of sensory attributes of bread prepared from millet-based composite flours. LWT - Food Science and Technology, 48(2), 276-282. http:// dx.doi.org/10.1016/j.lwt.2012.03.026.

Singh, K. P., Mishra, H. N., \& Saha, S. (2010). Moisture-dependent properties of barnyard millet grain and kernel. Journal of Food Engineering, 96(4), 598-606. http://dx.doi.org/10.1016/j.jfoodeng.2009.09.007. 
Suma, P. F., \& Urooj, A. (2014). Nutrients, antinutrients \& bioaccessible mineral content (in vitro) of pearl millet as influenced by milling. Journal Food Science and Technology, 51(4), 756-761. http://dx.doi. org/10.1007/s13197-011-0541-7. PMid:24741171

Teixeira, E., Meinert, E. M., \& Barbetta, P. A. (1987). Análise sensorial de alimentos. Florianópolis: UFSC.

Valencia, I., O’Grady, M. N., Ansorena, D., Astiasarán, I., \& Kerry, J. P. (2008). Enhancement of the nutritional status and quality of fresh pork sausages following the addition of linseed oil, fish oil and natural antioxidants. Meat Science, 80(4), 1046-1054. http://dx.doi. org/10.1016/j.meatsci.2008.04.024. PMid:22063835

Wyncke, W. (1970). Direct determination of the thiobarbituric acid value in trichloroacetic acid extracts of fish as a measure of oxidative rancidity. Fett Wissenschaft Technologie, 72(12), 1084-1087.

Zhang, L. Z., \& Liu, R. H. (2015). Phenolic and carotenoid profiles and antiproliferative activity of foxtail millet. Food Chemistry, 174, 495-501. http://dx.doi.org/10.1016/j.foodchem.2014.09.089. PMid:25529711 